the teaching staff at Cranfield since 1946. First appointed as a lecturer in the Department of Aerodynamics, he was promoted to senior lecturer in 1950 and to deputy head of the Department in 1955. He has played a major part in the development of the Aerodynamies Laboratory and its research activities. Prof. Lilley is a recognized authority on turbulent flow and its relationship to aerodynamic noise and is chairman of the Noise Research Committee of the Aeronautical Research Council. Other fields of research in which Prof. Lilley has made important contributions include hypersonic flow and its related problems, boundary layers, the design and operation of wind-tunnels and their associated instrumentation and problems of fluid motion. $\mathrm{He}$ is a Fellow of the Royal Aeronautical Society, and a member of the Society's Man-Powered Aircraft Group Committee.

\section{Agricultural Research Council Food Research Institute, Norwich: Prof. S. R. Elsden}

Prof. S. R. ELsDen, professor of microbiology in the University of Sheffield and honorary director of the Agricultural Research Council's Unit of Microbiology, has been appointed the first director of the Agricultural Research Council's now Food Research Instituto at Norwich; he will take up his appointment on July 1. Prof. Elsden graduated from Cambridge in 1936 with first-class honours in Part II of the Natural Sciences Tripos in biochemistry. In 1937 he was appointed assistant lecturer and, later, lecturer in physiology in the University of Edinburgh. In 1943 he returned to Cambridge as a member of the scientific staff of the Agricultural Research Council's Unit of Animal Physiology in the Department of Physiology. Prof. Elsden's early research dealt with bacterial fermentation, and he was much influenced by the work of the late Marjory Stephenson. He was the first worker to demonstrate that the formation of succinic acid in the fermentation of glucose by Escherichia coli is dependent on the presence of carbon dioxide. His research in the Unit of Animal Physiology was concerned mainly with rumen bacteria and he has retained an interest in these organisms, especially in their fatty acid metabolism. In 1946 he went to the United States for a year to work with Prof. C. B. van Niel and Prof. H. A. Barker of the University of California. This visit stimulated him to diroct his attention to the metabolism of photosynthetic bacteria. In 1948, Prof. Elsden was appointed senior lecturer in microbiology in the Department of Bacteriology in the University of Sheffield, and in 1952 he was placed in charge of the new Department of Microbiology in the University and appointed honorary director of the Agricultural Research Council's Unit of Microbiology. He held an exchange professorship in the Department of Bacteriology of the University of Illinois for six months during 1956, and was appointed West Riding professor of microbiology in the University of Sheffield in 1959. At Sheffield Prof. Elsden has extended his researches into the physiology of microbial growth, and particularly into the relationship between growth and adenosine triphosphate production. He has built up a strong team of microbiologists some of whom will go with him to Norwich.

\section{Science in Parliament:}

Cancer Research

Is a written answer in the House of Commons on November 23, the Secretary of State for Education and Science, Mr. M. Stewart, said that the Medical Research Council expected to spend about $£ 1,029,000$ on cancer research, excluding capital expenditure. The Government supported cancer research by financial grants to universities and medical schools through the University Grants Committee and at hospitals within the National Health Service. Much basic research which could throw light on this disease was supported from public funds, while in 1963 the British Empire Cancer Campaign for Research approved expendituro of $£ 1,314,787$ on research and related activities, and the Imperial Cancer Research Fund in 1962-63 expended $£ 1,232,000$.

Under-water Research

IN reply to a question in the Houso of Lords on November 26, Lord Shackleton stated that there was already very close co-operation betweon the Ministry of Defence, the Fisheries Departments and other agencies and other Government-supported bodies concorned with research under water. Pressed further for an assurance that an effective co-ordinating body would be set up, Lord Shackleton said that he assumed that Lord Wakefield was referring particularly to diving techniques, which could be used in many fields and especially for research purposes. He questioned whether this was a field in which the Government should attempt to co-ordinate all activities, but it would be interested to receive any representations from Lord Wakefield or from the British Sub-Aqua Club, to which the Department of Education and Science made a direct subvention of $£ 1,500$.

\section{Overseas Research and Development}

IN a written answer in the House of Commons on November 25, the Minister of Overseas Development, Mrs. B. Castle, announced that the targets for sending volunteers overseas in 1965 would be increased from 1,000 to 1,200 for graduates and from 300 to 400 for school-leavers and apprentices. The Government would, as already arranged, pay 75 per cent of the British costs of this programme, which were estimated at $£ 900,000$.

Industrial Research and Development

IN a written statement in the House of Commons on November 26, the Prime Minister stated that the Minister of Technology had the general responsibility of guiding and stimulating a major effort to bring advanced technology and new processes into British industry. The methods used would include an intensified use of the appropriate research stations and of the National Research Development Corporation, civil development contracts, and investigations to identify particular industries or parts of industries suitable for action. The Minister would consider what changes might be made in the arrangements for procurement financed by public funds to contribute to the promotion of technological advance. $\mathrm{He}$ would initiate investigations of the status of the engineering profession. All these tasks would be undertaken in close consultation with the other Departments concorned.

As already announced, the Minister would be responsible for the Atomic Energy Authority and the National Research Development Corporation and would take over elements of the Dopartment of Scientific and Industrial Research headquarters which have been concerned with research and technical devolopment in industry. The Ministry of Technology would in future be the sponsoring department for the machine tools, electronics, telecommunications and computer industries. Close rolations would be established with the British Standards Institution and the Ministry would support its work in the engineering field. Mr. Wilson added that in the Science and Technology Bill now before Parliament it was proposed to extend the powers of the Atomic Finergy Authority to permit the Authority to undertake research and dovolopment outside the nuclear field, and legislative action would also be taken to increaso the powers and resources of the National Rescarch Development Corporation.

Research Councils

THE statement on November 26 was complemented by a written answer given on the same day by the Secretary of State for Education and Science outlining the arrangements that would be made following tho enactment of the Science and Technology Bill. The Secretary of State 